\title{
Derivatization Does Not Influence Antimicrobial and Antifungal Activities of Applanoxidic Acids and Sterols from Ganoderma spp.
}

\author{
Artur Smania Jr., ${ }^{\text {,* }}$, Elza F. A. Smania ${ }^{\mathrm{a}}$, Franco Delle Monache ${ }^{\mathrm{b}}$, \\ Moacir G. Pizzolattic ${ }^{\mathrm{c}}$, and Giuliano Delle Monache ${ }^{\mathrm{a}}$ \\ a Departamento de Microbiologia e Parasitologia, Universidade Federal de Santa Catarina, \\ Florianopolis, SC 88040-900, Brazil. Fax: +55-48-3319258. E-mail: smania@mbox1.ufsc.br, \\ artursmania@hotmail.com \\ b Istituto di Biochimica e Biochimica Clinica, Università Cattolica Del Sacro Cuore, Roma \\ Italy \\ c Departamento de Química, Universidade Federal de Santa Catarina, Florianopolis, Brazil \\ * Author for correspondence and reprint requests \\ Z. Naturforsch. 61c, 31-34 (2006); received July 7, 2005 \\ Applanoxidic acids and sterols, isolated from Ganoderma spp., were acetylated and/or \\ methylated. The antibacterial activity against Escherichia coli and Staphylococcus aureus and \\ the antifungal activity against Candida albicans and Trichophyton mentagrophytes of the de- \\ rivatives were investigated by a microdilution method, and compared with those of the natu- \\ ral products. Both natural and modified compounds exhibited comparable antibacterial and \\ antifungal activities in a range of 1.0 to $>2.0 \mathrm{mg} / \mathrm{ml}$ minimal inhibitory concentration.
}

Key words: Applanoxidic Acids, Sterols, Derivatization, Antibacterial and Antifungal Activity

\section{Introduction}

Applanoxidic acids $(\mathbf{1}-\mathbf{5})$ are exclusive triterpene metabolites from Ganoderma species (Ganodermataceae Donk), while sterols $(\mathbf{6}-\mathbf{8})$ were isolated from other Basidiomycetes, as Pycnoporus and Rigidoporus, in addition to Ganoderma (Chen et al., 1999; Chyr and Shiao, 1991; Smânia et al., 2001). Their biological activities have been described previously (Gerber et al., 2000; Smânia et al., 1999, 2003). This paper deals with the antibacterial and antifungal activities of methyl/acetyl derivatives in comparison with those of the natural compounds.

\section{Material and Methods}

\section{Fungi}

A basidioma of Ganoderma applanatum was collected from decayed wood in a forest of Southern Brazil in 1995; a voucher specimen was deposited at the Herbarium FLOR, Department of Botany, Federal University of Santa Catarina, Brazil, under the number FLOR 11.470. Four basidiomata of Ganoderma australe were collected in Florianopolis, Santa Catarina, Brazil; voucher specimens are deposited in the same Herbarium as above, under the number FLOR 11.723, 11.727, 11.728 , and 11.729 .

\section{Natural products}

Applanoxidic acids A (1), C (2), F (3), G (4), and $\mathrm{H}(\mathbf{5})$ were isolated from $G$. australe (Gerber et al., 2000). 5 $\alpha$-Ergost-7en- $3 \beta$-ol (6), $5 \alpha$-ergost7,22-dien-3 $\beta$-ol (7), and 5,8-epidioxy- $5 \alpha, 8 \alpha$-ergost6,22-dien-3 $\beta$-ol (8) were isolated from both $G$. applanatum (Smânia et al., 1999) and G. australe (Gerber et al., 2000) (Fig. 1).

\section{Acetylation of applanoxidic acids}

Compounds 1, 4, and 5 were treated with $\mathrm{Ac}_{2} \mathrm{O}$ in pyridine (1:1) at room temperature for $24 \mathrm{~h}$, to yield the corresponding acetyl derivatives 1a, $\mathbf{4 a}$, and $\mathbf{5 a}$, as confirmed by the appropriate signals for the OCOMe groups in ${ }^{1} \mathrm{H}$ and ${ }^{13} \mathrm{C}$ NMR spectra $\left(\mathrm{CDCl}_{3}\right.$, TMS as internal standard) (Fig. 1).

\section{Methylation of applanoxidic acids}

Compounds $\mathbf{1}-\mathbf{5}$ were treated with a satured diazomethane solution $\mathrm{Et}_{2} \mathrm{O}$ at room temperature for $2 \mathrm{~h}$, to yield the corresponding methyl derivatives $\mathbf{1 m}-\mathbf{5 m}$, as confirmed by the appropriate signals for the COOMe groups in ${ }^{1} \mathrm{H}$ and ${ }^{13} \mathrm{C}$ NMR spectra (Fig. 1). 


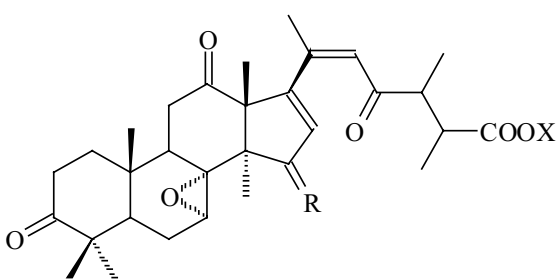

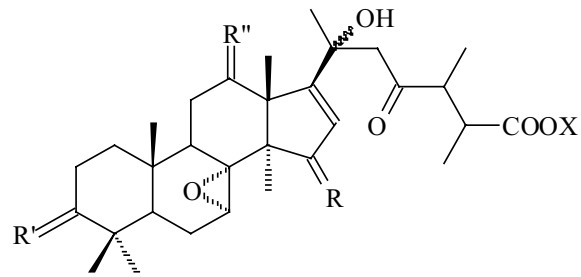

$\begin{array}{lll} & \mathrm{R} & \mathrm{X} \\ \mathbf{1} & \mathrm{H}, \mathrm{OH} & \mathrm{H} \\ \mathbf{3} & \mathrm{O} & \mathrm{H} \\ \mathbf{1 a} & \mathrm{H}, \mathrm{OAc} & \mathrm{H} \\ \mathbf{1 m} & \mathrm{H}, \mathrm{OH} & \mathrm{Me} \\ \mathbf{1 d} & \mathrm{H}, \mathrm{OAc} & \mathrm{Me} \\ \mathbf{3 m} & \mathrm{O} & \mathrm{Me}\end{array}$

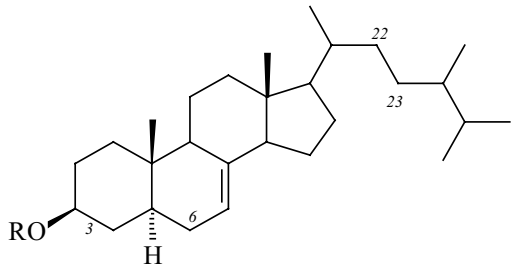

$\begin{array}{lllll} & \mathrm{R} & \mathrm{R}^{\prime} & \mathrm{R} " & \mathrm{X} \\ \mathbf{2} & \mathrm{O} & \mathrm{O} & \mathrm{O} & \mathrm{H} \\ \mathbf{4} & \mathrm{H}, \mathrm{OH} & \mathrm{O} & \mathrm{O} & \mathrm{H} \\ \mathbf{5} & \mathrm{O} & \mathrm{H}, \mathrm{OH} & \mathrm{H}, \mathrm{OH} & \mathrm{H} \\ \mathbf{2 m} & \mathrm{O} & \mathrm{O} & \mathrm{O} & \mathrm{Me} \\ \mathbf{4 a} & \mathrm{H}, \mathrm{OAc} & \mathrm{O} & \mathrm{O} & \mathrm{Me} \\ \mathbf{4 m} & \mathrm{H}, \mathrm{OH} & \mathrm{O} & \mathrm{O} & \mathrm{Me} \\ \mathbf{4 d} & \mathrm{H}, \mathrm{OAc} & \mathrm{O} & \mathrm{O} & \mathrm{Me} \\ \mathbf{5 a} & \mathrm{O} & \mathrm{H}, \mathrm{OAc} & \mathrm{H}, \mathrm{OAc} & \mathrm{H} \\ \mathbf{5 m} & \mathrm{O} & \mathrm{H}, \mathrm{OH} & \mathrm{H}, \mathrm{OH} & \mathrm{Me} \\ \mathbf{5 d} & \mathrm{O} & \mathrm{H}, \mathrm{OAc} & \mathrm{H}, \mathrm{OAc} & \mathrm{Me}\end{array}$

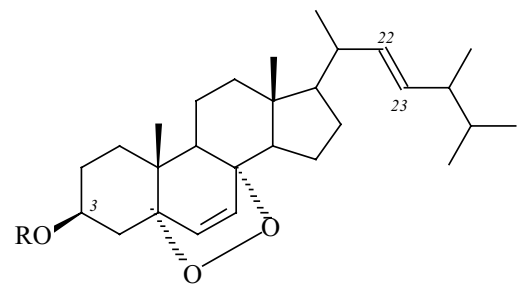

Fig. 1. Triterpenes and sterols isolated from Ganoderma spp. and their derivatives.

\section{Acetylation of applanoxidic acid methyl esters}

Compounds $\mathbf{1 m}, \mathbf{2 m}$ and $\mathbf{5 m}$ were acetylated, as described above, to yield $\mathbf{1 d}, \mathbf{2 d}$, and $\mathbf{5 d}$. The reactions were confirmed by the appropriate signals for the OCOMe groups in ${ }^{1} \mathrm{H}$ and ${ }^{13} \mathrm{C}$ NMR spectra (Fig. 1).

\section{Acetylation of sterols}

$5 \alpha$-Ergost-7-en-3 $\beta$-ol (6), $5 \alpha$-ergost-7,22-dien$3 \beta$-ol (7), and 5,8-epidioxy- $5 \alpha, 8 \alpha$-ergost-6,22-dien$3 \beta$-ol (8) yielded by acetylation the derivatives 6a-8a, respectively, as confirmed by ${ }^{1} \mathrm{H}$ and ${ }^{13} \mathrm{C}$ NMR spectra (Fig. 1).

\section{Antibacterial test}

The eight natural products and the fourteen derivatives were tested against Escherichia coli ATCC 25922 and Staphylococcus aureus ATCC
25923 using a microdilution method and tetracycline as a reference agent. All the compounds were dissolved in dimethylsulfoxide (DMSO) and diluted $(2.0-0.0156 \mathrm{mg} / \mathrm{ml})$ in a Mueller-Hinton broth. $100 \mu \mathrm{l}$ from each dilution, as well as $100 \mu \mathrm{l}$ of the vehicle (Mueller-Hinton broth plus DMSO), were poured in one of the 96 wells of a sterilized microplate. Each well was inoculated with $5 \mu \mathrm{l}$ of bacterial inoculum $\left(10^{6} \mathrm{CFU} / \mathrm{ml}\right)$. The procedure was performed in duplicate and the microdilution trays were incubated at $36^{\circ} \mathrm{C}$ for $18 \mathrm{~h}$. The optical density was read in an ELISA apparatus while the microbial growth was confirmed with INT ( $p$-iodonitrotetrazolium violet). The minimal inhibitory concentration (MIC), defined as the lowest concentration for each substance that produced inhibition of bacterial growth, is reported in Table I. 


\begin{tabular}{ccccc}
\hline \multirow{2}{*}{ Compound } & \multicolumn{2}{c}{ Bacteria } & \multicolumn{2}{c}{ Fungi } \\
\cline { 2 - 5 } & E. coli & S. aureus & C. albicans & T. mentagrophytes \\
\hline $\mathbf{1}$ & 2.0 & 2.0 & $>2.0$ & 0.5 \\
$\mathbf{1 a}$ & 2.0 & 2.0 & 2.0 & 2.0 \\
$\mathbf{1 m}$ & 2.0 & 2.0 & 2.0 & 2.0 \\
$\mathbf{1 d}$ & 2.0 & 1.0 & 1.0 & 1.5 \\
$\mathbf{2}$ & 2.0 & 1.0 & 2.0 & 2.0 \\
$\mathbf{2 m}$ & 2.0 & 2.0 & 2.0 & 2.0 \\
$\mathbf{3}$ & 2.0 & $>2.0$ & 1.0 & 1.0 \\
$\mathbf{3 m}$ & 2.0 & 2.0 & 1.0 & 1.25 \\
$\mathbf{4}$ & 2.0 & 2.0 & 1.0 & 2.0 \\
$\mathbf{4 a}$ & 2.0 & 2.0 & 2.0 & 2.0 \\
$\mathbf{4 m}$ & 2.0 & 1.0 & 2.0 & 2.0 \\
$\mathbf{4 d}$ & 2.0 & $>2.0$ & $>2.0$ & 1.5 \\
$\mathbf{5}$ & 2.0 & 1.0 & 2.0 & 1.0 \\
$\mathbf{5 a}$ & 2.0 & 2.0 & 1.0 & 1.0 \\
$\mathbf{5 m}$ & 2.0 & 2.0 & $>2.0$ & 1.25 \\
$\mathbf{5 d}$ & 2.0 & 2.0 & $>2.0$ & 1.0 \\
$\mathbf{6}$ & 2.0 & 2.0 & $>2.0$ & $>2.0$ \\
$\mathbf{6 a}$ & 2.0 & 2.0 & 2.0 & 1.0 \\
$\mathbf{7}$ & 2.0 & 2.0 & $>2.0$ & $>2.0$ \\
$\mathbf{7 a}$ & $>2.0$ & $>2.0$ & $>2.0$ & $>2.0$ \\
$\mathbf{8}$ & 1.0 & 1.0 & 2.0 & 2.0 \\
$\mathbf{8 a}$ & 2.0 & $>2.0$ & $>2.0$ & 2.0 \\
Reference & 0.002 & 0.001 & 0.1 & 0.0006 \\
\hline & & & &
\end{tabular}

Table I. Antibacterial and antifungal activities (MIC*) of $G a$ noderma spp. metabolites and their derivatives.

* Minimal inhibitory concentration $(\mathrm{mg} / \mathrm{ml})$.

a Tetracycline (for bacteria) and fluconazole (for fungi).

\section{Antifungal test}

The same substrates were tested against Candida albicans and Trichophyton mentagrophytes using the microdilution method and fluconazole as a reference agent. The same procedure as above was used for a $5 \mu \mathrm{l}$ fungal inoculum $\left(10^{5} \mathrm{CFU} / \mathrm{ml}\right)$. Incubation was at $30^{\circ} \mathrm{C}$ for $72 \mathrm{~h}$. MIC values, as the lowest concentration for each substrate resulting in the absence of fungal growth, are also reported in Table I.

\section{Results and Discussion}

As shown in Table I, the Gram-positive strain $S$. aureus was slightly more sensitive than the Gramnegative strain $E$. coli, while the dermatophyte $T$. mentagrophytes was also slightly more sensitive than the yeast $C$. albicans. The antimicrobial activities of natural and modified compounds were comparable. Derivatization of triterpenes influenced the MIC value only in a few cases and the change did not concern more than one dilution, whereas acetylation of sterols was essentially negative. For the antifungal activities, which varied in the same range $(1.0$ to $>2.0 \mathrm{mg} / \mathrm{ml})$, similar considerations are valid.

In conclusion, the structural modifications did not promote a better interaction of the substrates with the target. Actually, the co-administration of natural products with alkaloids (efflux pump inhibition) remains a good perspective for the use of these secondary metabolites as prototypes for new antibiotics (Bambeke et al., 2003; Tegos et al., 2002). 
Bambeke F. V., Glupczynski Y., Plésiat P., Pechère J. C., and Tulkens P. M. (2003), Antibiotic efflux pumps in prokaryotic cells: occurrence, impact on resistence and strategies for the future of antimicrobial therapy. J. Antimicrob. Chemother. 51, 1055-1065.

Chen D. H., Shiou W. Y., Wang K. C., Huang S. Y., Shie Y. T., Tsai C. M., Shie J. F., and Chien K. D. (1999), Studies on the triterpenoid constituents of the spores of Ganoderma lucidum (Curt.:Fr.) P. Karst. (Aphyllophoromycetideae). J. Chin. Chem. Soc. 46, 47.

Chyr R. and Shiao J. D. (1991), Liquid chromatographic characterization of the triterpenoids patterns in $\mathrm{Ga}$ noderma lucidum and related species. J. Chromatogr. 542, 327.

Gerber A. L., Smânia A. Jr., Delle Monache F., Biachi N. Jr., and Smania E. F. A. (2000), Triterpenes and sterols from Ganoderma australe (Fr.) Pat. (Aphyllophoromycetidae). Int. J. Med. Mushr. 2, 303-311.
Smânia A. Jr., Delle Monache F., Smânia E. F. A., and Cuneo R. S. (1999), Antibacterial activity of steroidal compounds isolated from Ganoderma australe (Fr.) Pat. (Aphyllophoromycetidae) fruit body. Int. J. Med. Mushr. 1, 325.

Smânia A. Jr., Delle Monache F., Loguercio-Leite C., Smânia E. F. A, and Gerber A. L. (2001), Antimicrobial activity of Basidiomycetes. Int. J. Med. Mushr. 3, 87.

Smânia E. F. A., Delle Monache F., Smânia A. Jr., Yunes R. A., and Cuneo R. S. (2003), Antifungal activity of sterols and triterpenes isolated from Ganoderma annulare. Fitoterapia 74, 375-377.

Tegos G., Stermitz F. R., Lomovskaya O., and Lewis K. (2002), Multidrog pump inhibitors uncover remarkable activity of plant antimicrobials. Antimicrob. Agents Chemother. 46, 3133-3141. 